\title{
Were Juan Gerson the Illustrator and Gaspar de Torres the Author of the Voynich Codex?
}

\author{
Jules JANICK ${ }^{1 *}$, Arthur O. TUCKER ${ }^{2}$ \\ ${ }^{1}$ Purdue University, Department of Horticulture and Landscape Architecture, 625 Agriculture Mall Drive, \\ West Lafayette IN 47907-2010, USA; janick@purdue.edu ( ${ }^{*}$ corresponding author) \\ ${ }^{2}$ Delaware State University, Department of Agriculture and Natural Resources, 1200 N. Dupont Highway, \\ DoverDE 19901,USA; atucker@desu.edu
}

\begin{abstract}
The bizarre Voynich Codex, discovered in 1912 in Italy by the Polish book dealer Wilfrid Voynich (1864-1930), is written in a coded language with has eluded decipherment despite repeated attempts by world renowned cryptologists. Plant, animal, and mineral identifications as well as iconographic evidence indicate that the Voynich Codex is a $16^{\text {th }}$ century work of New Spain. A typographical ligature based on the initials "JGT" in the first botanical image (folio 1v) suggests that artist was Juan Gerson, Tlacuilo, indigenous painter known for the apocalypse paintings in the monastery Asuncion de Nuestra Senora of Tecamachalco. The name "Gasp. Torres" also embedded in the first botanical image suggests that the author could be Gaspar de Torres, medical doctor, estate lawyer, master of students at the College of Santa Cruz in Tlatelolco from 1568-1572, and Governor of Cuba in 1580. Iconographic similarities between the paintings of Juan Gerson and the Voynich Codex, along with a biography of Gaspar de Torres provide additional support for this conjecture.
\end{abstract}

Keywords: Gaspar de Torres, Juan Gerson, herbal, New Spain, Hugh O’Neill, Voynich Codex, Wilfrid Voynich

\section{Introduction}

In 1912, a mysterious illustrated manuscript was discovered in Italy by the Polish book dealer Wilfrid Voynich (18641930). Written in a coded language, it has eluded decipherment despite repeated attempts by renowned cryptologists. The manuscript, now best referred to as the Voynich Codex, was at one time in the collection (Kunsthammer) of the Holy Roman Emperor Rudolph II (1552-1612) based on a 1665 letter by Johannes Marcus Marci (Zandbergen, 2016) and confirmed by signature of the imperial chemist of the court, Jacobi a Tepenecz, the ennobled name of Jacob Horčicky, on the first page (Zyats et al., 2016).

The profusely illustrated manuscript is in large part an herbal but also contains numerous illustrations of hundreds of nude nymphs cavorting in pools connected by strange vascular systems; various magic circles consisting of astronomical images, a zodiac with many New World animals, and various pages of text that may be medical prescriptions, poems or incantations (Fig. 1). Of the estimated 320 plants or plant parts illustrated, 59 have been identified as indigenous to Mesoamerica. Of 16 animal species identified, 14 are also indigenous and 2 are species introduced by the Spanish (cattle and sheep). The text written in an unknown alphabet or syllabary in an unknown language has been partially deciphered based on labels connected to many of the plants (Tucker and
Talbert, 2013). We have identified a map on folio $86 \mathrm{v}$ based on kabbalah imagery and identified the New City of Jerusalem (Puebla de Los Angeles) founded by Fray Toribio de Benavente (known as Motolinía) in 1530, one of the 12 priests who entered Mexico in 1524, to convert and teach the indigenous population (Motolinia, 1951). However, the artist and author of the Voynich Codex are unknown. The object of the present paper is to identify both the illustrator and author of the Voynich Codex and determine the dates of execution.

\section{The Voynich Codex as a Mesoamerican Manuscript}

The earliest evidence that the Voynich Codex might have a Mesoamerican origin was a remarkable paper by Dr. Rev. Hugh O'Neill (1944), who identified two New World plants, sunflower (Fig. 1A) and capsicum pepper. These identifications dated the codex as post-Columbus. Further botanical analysis by Arthur O. Tucker and Rex Talbert (2013) identified 37 plants, a mineral (boleite), as well as 7 animals as indigenous to the New World. This was extended to 59 phytomorphs (plant illustrations) of 56 species by Tucker and Janick (2016). No indigenous European, Asian, African, Australian, or South American plants have been identified other than circumboreal species. Furthermore we identified a large fold-out section made up of six pages (folio 86v) with 


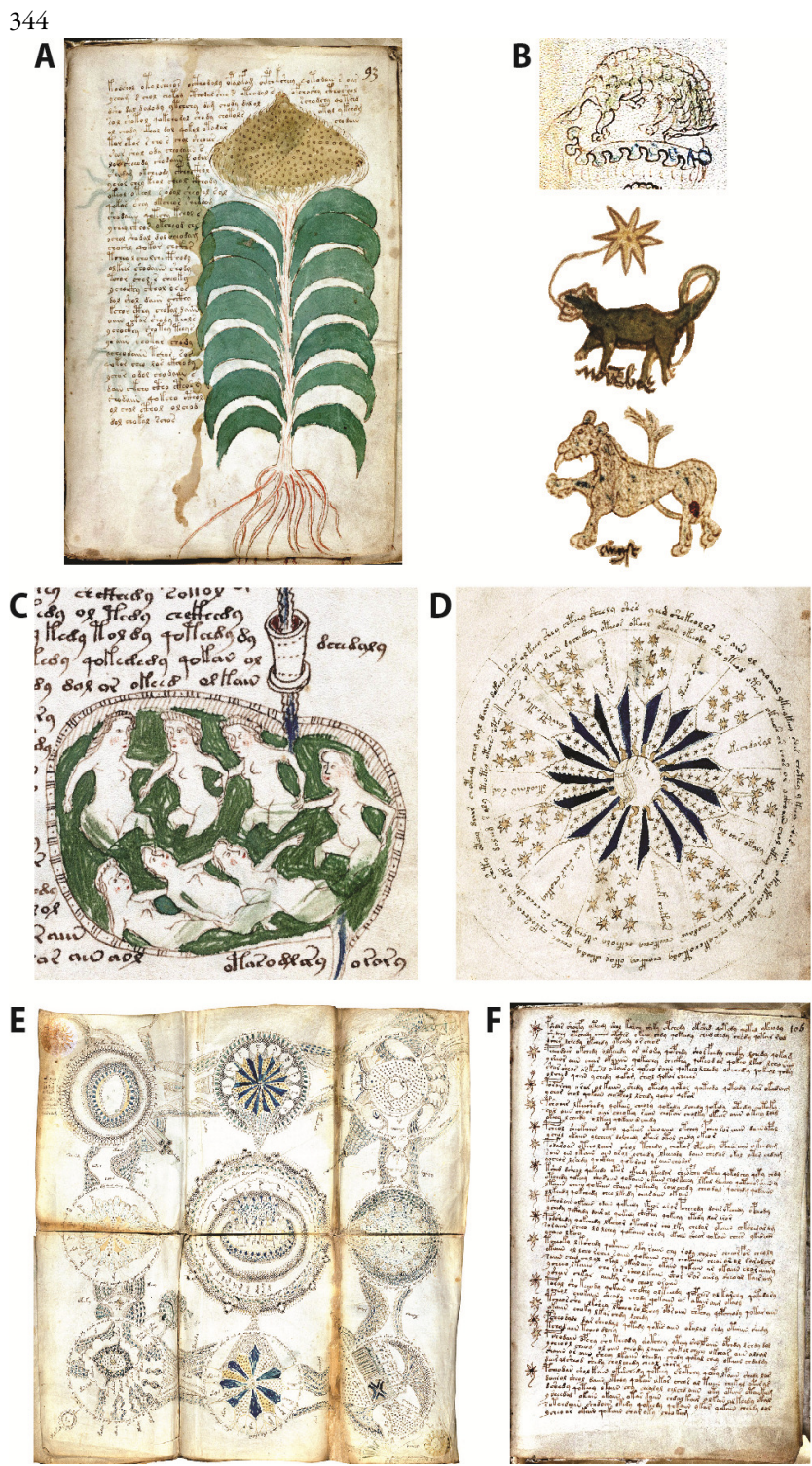

Fig. 1. Representative illustrations of the Voynich Codex: (A) sunflower (Helianthus annua) in the Herbal Section (folio 93v); (B) animals indigenous to New Spain (from top to bottom) armadillo (Cabassous unicinctus), jaguarondi (Puma yagouraoundi) and ocelot (Leopardus pardalis); (C) bathing nymphs in the Balneological Section (folio 78r); (D) circle with stars and sun in the Astrological Section (folio 67r); (E) Folio 86v with kabbalah-like imagery representing a map of central Mexico; (F) Text in symbolic letters of the Recipe / Stars Section (folio 106r)

kabbalah-like images (Fig. 1E) to be a map with five cities and three volcanos of central Mexico. Identifications of phytomorphs, zoomorphs, a geomorph, five Mexican cities (one, Puebla de Los Angeles founded in 1530 by Fray Toribo de Benavente known as Motolinía, the poor one) are evidence that the Voynich Codex is a New World manuscript. These identifications are consistent with the assumption that the manuscript originated in Colonial New Spain in the $16^{\text {th }}$ century. The object of the present paper is to identify the illustrator and author of the Voynich Codex based on iconographic and biographical evidence.

\section{Identification of Illustrator and Author}

Juan Gerson, Tlacuilo

The plant illustrations of the Voynich Codex have secrets to reveal beyond their identification. A close examination of the leaves and bud of Ipomoea aborescens in folio 1v (Fig. 2B), the first illustration reveals a symbol or glyph resembling a typographic ligature that appears to be made up of three letters, JGT, and resemble an animal brand or monogram (Fig. 3). The three letters are in the escritura cortesana, handwriting style popular in 16th century Spain (Comegys, 2014). Of all the artists in 16th century New Spain, the only one with the initials JGT was Juan Gerson, Tlacuilo.

Juan Gerson was an indigenous indio ladino, a Hispanicized person of Amerindian descent, in $16^{\text {th }}$ century Colonial New Spain known as a tlacuilo (Aztec illustrator) whose baptismal name honored a French theologian, 13631429 (Azpeitia, 1972). Juan's prominent father, Tomás Tlacochteuctli, later adopted the surname Gerson (Townsend, 2016). Juan Gerson attended La Escuela de San José de los Naturales established by Fray Pedro de Gante to train the sons of the Aztec nobility (Francisco de la Maza, 1968, quoted in Sanchis Amat, 2012) and most likely was trained in fine arts and crafts. In 1562, the talented Juan Gerson completed a cycle of 28 paintings plus the Franciscan seal on amate (traditional bark paper of the Aztecs) that decorate the ceiling of the Franciscan church Asuncion de Nuestra Señora in Tecamachlaco (Jaws of Stone), a small city $57 \mathrm{~km}$ east of Puebla. This extraordinary work illustrating the biblical apocalypse of Saint John, a favorite Franciscan theme in these troubled times, was based on European engravings, and has been traced to woodcuts made early in the $16^{\text {th }}$ century (Niedermeier, 2002).

Juan Gerson stands out from his contemporaries, not only because he was a tlacuilo who was identified by name in the church at Tecamachalco, but also because of his recognition by the Spanish authorities of New Spain. Juan's father Tomás requested permission to go on horseback in 1555, and in 1592; Juan Gerson was granted the extraordinary rights for upwardly mobile indio ladino to ride a saddled horse in Spanish clothing and carry a sword and dagger (Camelo Arredondo et al., 1964; Azpeitia, 1972; Landa Abrego, 1992). The ligated initials are very similar to horse brands (Fig. 3) registered in 1597 in Michoacán, Mexico (Du Bron, 2010). If Juan Gerson is the illustrator of the Voynich Codex, it is plausible that he would affix his signature or initials on the first folio. The use of initials in a monogram is not unique for artists in their works; the famous artist Albert Dürer (1471-1528), added his initials in many of his engravings.

The typographical evidence for Juan Gerson as the illustrator of the Voynich Codex is supported by the presence of his initials in the Apocalypse murals of 1562. In the painting of The Arresting of the Winds and the Elected, John 7:1-2, Juan Gerson has embedded "JGT" in the the lower gown of the annointing angel (Fig. 4). The " $\mathrm{J}$ " is very obvious, the "G" follows the folds of the gown, and the " $T$ " is fainter and upside down. Juan Gerson was inspired for the paintings at Tecamachalcho by the woodcuts of Erhard Schoen (after 1490-1524), Master IF (Jakob Farber or Jacques Lefevre, active 1516-1550), and Hans Holbein I (1497-1543) that were copied in Bibles printed in Germany and France (Camelo 

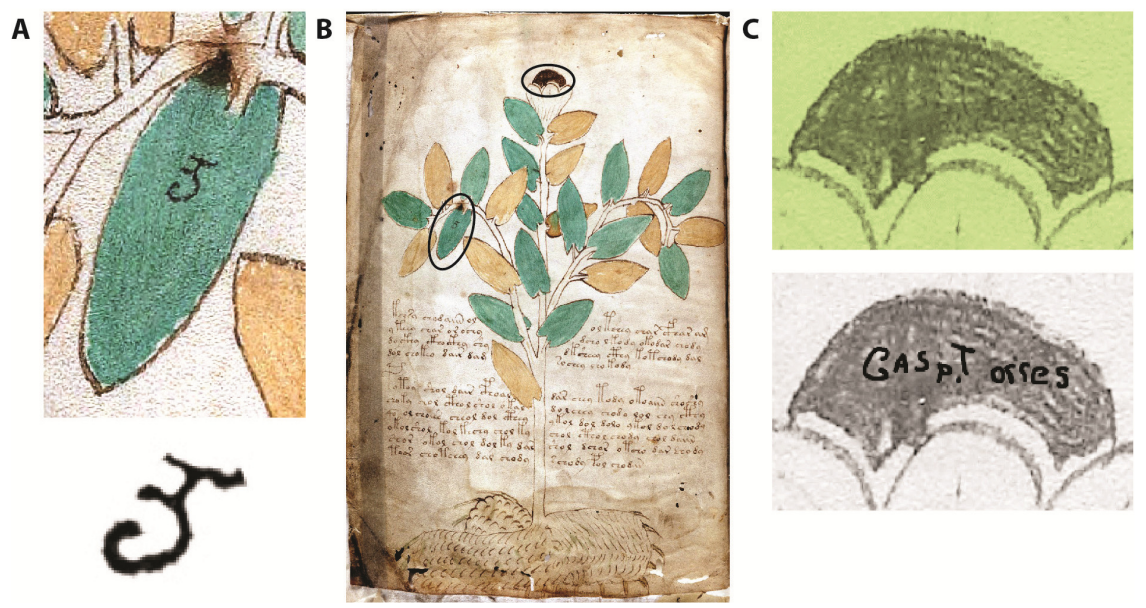

Fig. 2. Putative initials of Juan Gerson Tlacuilo and name of "Gasp. Torres" (Gaspar de Torres) embedded in folio 1v of the Voynich Codex: (A) leaf with initials; (B) folio 1v of the Voynich Codex; (C) bud with embedded name of "Gasp. Torres"

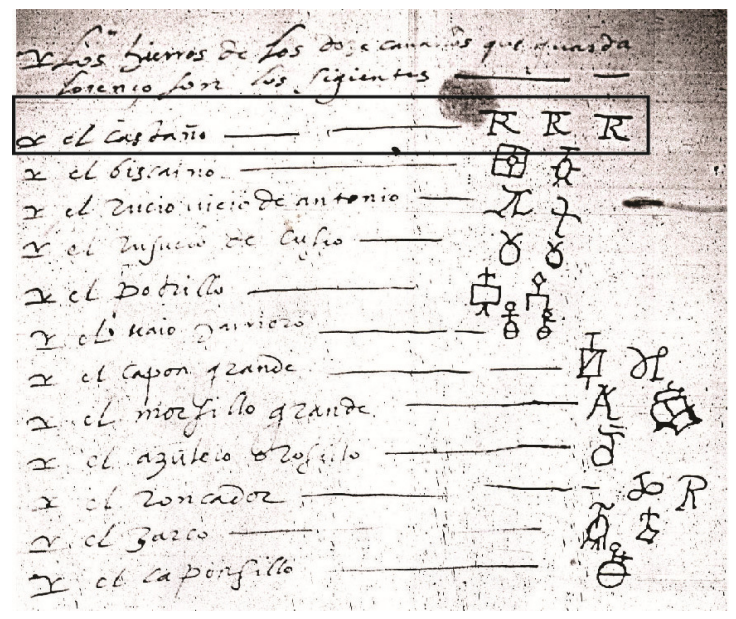

Fig. 3. Horse brands in Michoacán, Mexico, 1597. Note the similarity of the brand for El Castaño (The Bay) with the initials in folio 1v of the Voynich Codex in Fig. 1. Source: Du Bron (2010)

Arredondo et al., 1964). None of these sources have "JGT" embedded in the woodcuts.

Juan Gerson appears to be one of the artist painters of mural cycles in the residence, now known as the Casa de Deán, of Don Tomás de la Plaza, the dean of the cathedral in Puebla, México from 1583-1589 (Morrill, 2014). Art historians Gutiérrez Haces (2002) and Küegelgen (2013) report similar artistic elements between Casa del Deán murals and the Apocalypse paintings of Juan Gerson. The murals dating to 1584 were uncovered from whitewash and wallpaper in the mid-1930s and 1953, and restored in 2010. This attribution is affirmed by the presence of the initials "JGT", that appears to be embedded in the folds on the gown of The Triumph of Death (Fig. 4B). While these are faint because of considerable restoration in the $20^{\text {th }}$ century, the initials are similar to those found in Gerson's Apocalypse paintings. Iconographic similarities between the Apocalypse paintings, and Casa del
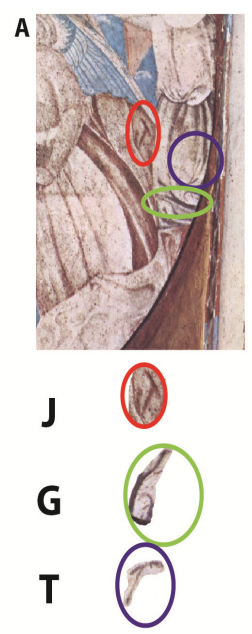

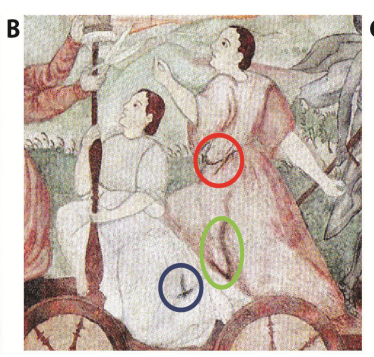

(v)

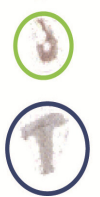

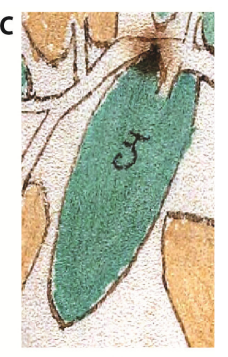

Fig. 4. Putative initials of Juan Gerson, Tlacuilo ("JGT"): (A) Apocalypse ceiling at Tecamachalco (The Arresting of the Winds and the Elected); (B) Salon of the Triumphs in Casa del Deán; (C) a leaf of Ipomoea arborescens on folio 1v of the Voynich Codex

Deán murals (Fig. 5) support the assumption that Juan Gerson is the artist involved in both works as well as the Voynich Codex. Iconographic examples are presented below.

\section{Water and Clouds}

The 28 paintings in the Church at Tecamachalco by Gerson were first examined to determined similarities to illustrations in the Voynich Codex. Water and clouds are illustrated in a similar manner in both the Voynich Codex (circle 2 in folio 86v) and Gerson's apocalypse images (Noah and the Ark, and Open Book in Angels Hand) (Fig. 6).

\section{Astronomical Images}

The cosmological section of the Voynich Codex is filled with images of the sun and moon, stars, and planets which are also found in Gerson's ceiling paintings (Fig. 7A-D). Stars are often six of seven pointed, and a cluster of seven stars known as 
346
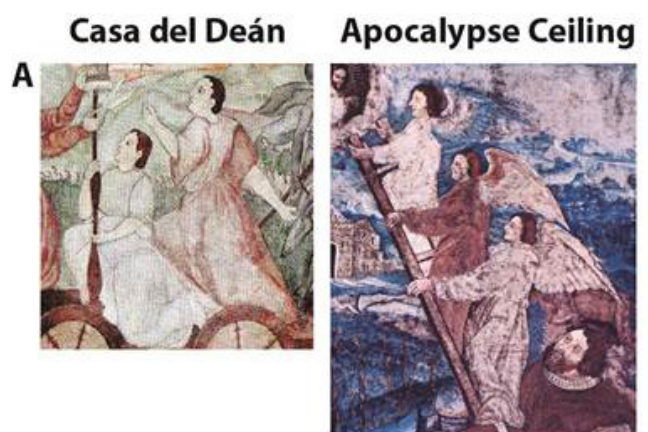

B
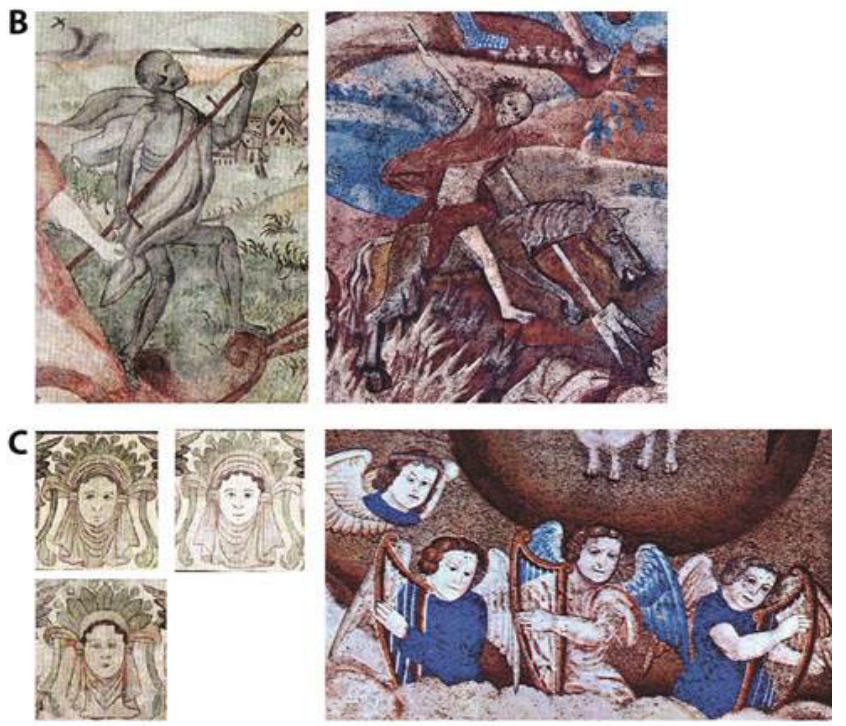

Fig. 5. Similarity of Casa de Deán murals (left) with images of Juan Gerson's apocalyptic images in the Franciscan church in Tecamachalco, Puebla (right): (A) close up of women in Triumph of Death in Casa del Deán (left) and angels in Gerson's Jacob's Ladder (right); (B) grim reaper in Casa del Deán (left) and Gerson's figure of Death in the Four Horsemen of the Apocalypse(right); (D) heads in frieze of Casa del Deán (left) and angels from Gerson's Vision of the lambs on Mount Zion (right)

the Pleiades is found in both Voynich Codex and the Apocalypse images (A). Note that both the sun (B) and the moon (C) have faces and the sun has prominent rays. We have surmised that a "starfish" symbol (D) in Voynich Codex represents planets and this same image is shown in The Plague of the Locusts with Eight Arms. The starfish planet symbol of Gerson's painting appears to be derived from a woodcut by an artist named IF (Jakob Farber or Jacques Lefevre). The close affinity of astronomical images add plausibility to the assumption that the Voynich Codex images and the Apocalypse images are by the same hand.

\section{Zodiac Signs}

The zodiac images in the Voynich Codex (Fig. 8) contain signs including cattle (cow and bull) representing Taurus (A); scales representing Libra (B); and a medieval dressed figure with a crossbow representing Sagittarius (C). There are various bulls in Gerson's Apocalypse paintings, all winged, but the horns in one resemble those of the Voynich Codex. The scales in the Voynich Codex representing Libra are included in the scene of The Four Riders of the Apocalypse. The cross-bowed archer in Voynich that represent the constellation Sagittarius is dressed very similar to a figure in the painting Erection of the Tower of Babal. This figure in the original woodcut is hatless, but both the figure in Voynich Codex and Gerson wear a similar hat.

\section{Birds}

Two images of caracara are found in the Voynich Codex, folio $86 \mathrm{r}$ (2), and there are a number of birds that appear to be the same in the Apocalypse paintings (Fig. 9). The third bird image from Gerson's Apocalypse ceiling is very close to the flying bird image in the Voynich Codex.

\section{Structures}

There are various similar architectural structures in Voynich Codex (left) and Gerson's Apocalypse paintings (right) that show remarkable similarities (Fig. 10). These include: (A) a bathing structures in the Voynich Codex and a windowed structure in one of the Apocalypse painting; (B) a number of towers in both; and similarity between the central circle of folio 86v of the Voynich Codex (C) representing New Celestial City of Jerusalem (Puebla de los Angeles) established by Motolinía in 1530 which shows a mantle of stars above six qubba, with Gerson's Vision of Jesus Christ and the Seven Candlesticks (D) which show a mystical figure surrounded by large candlesticks pointing to a cluster of 7 stars resembling the Pleiades, and The City of God (Jerusalem) painting (E) based on a Holbein woodcut shows one qubba (dome) in the middle, presumably the Dome of the Rock and 5 qubba in the wall.
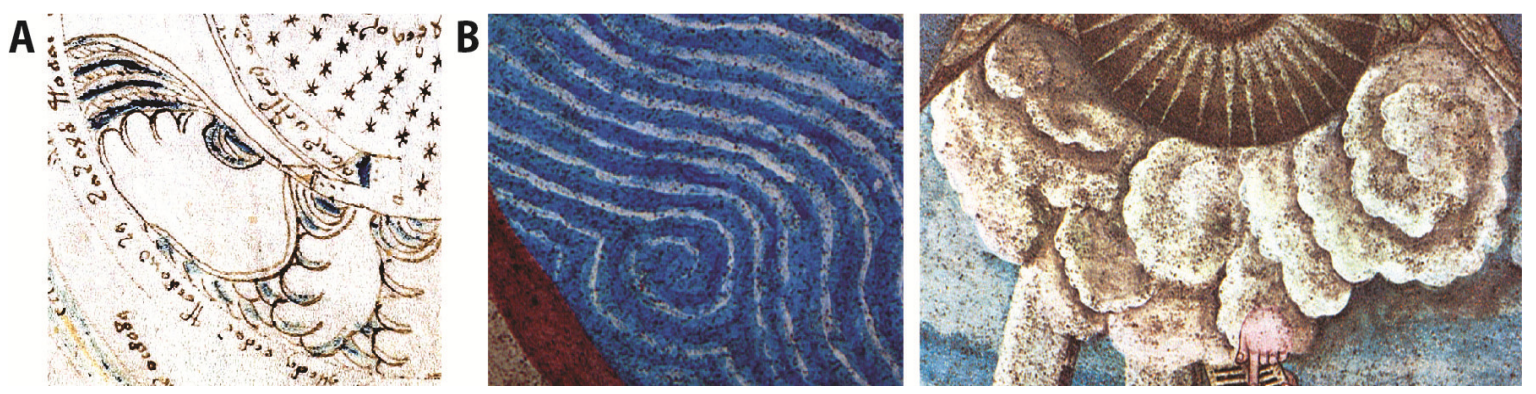

Fig. 6. Water and clouds in Voynich folio 86v and Gerson's Apocalypse paintings: (A) Circle 2 of folio 86v of Voynich Codex representing Huejozingo; (B) Gerson's Noah and the Ark; (C) Gerson's Open Book in Angels Hand (Azpeitia, 1972) 


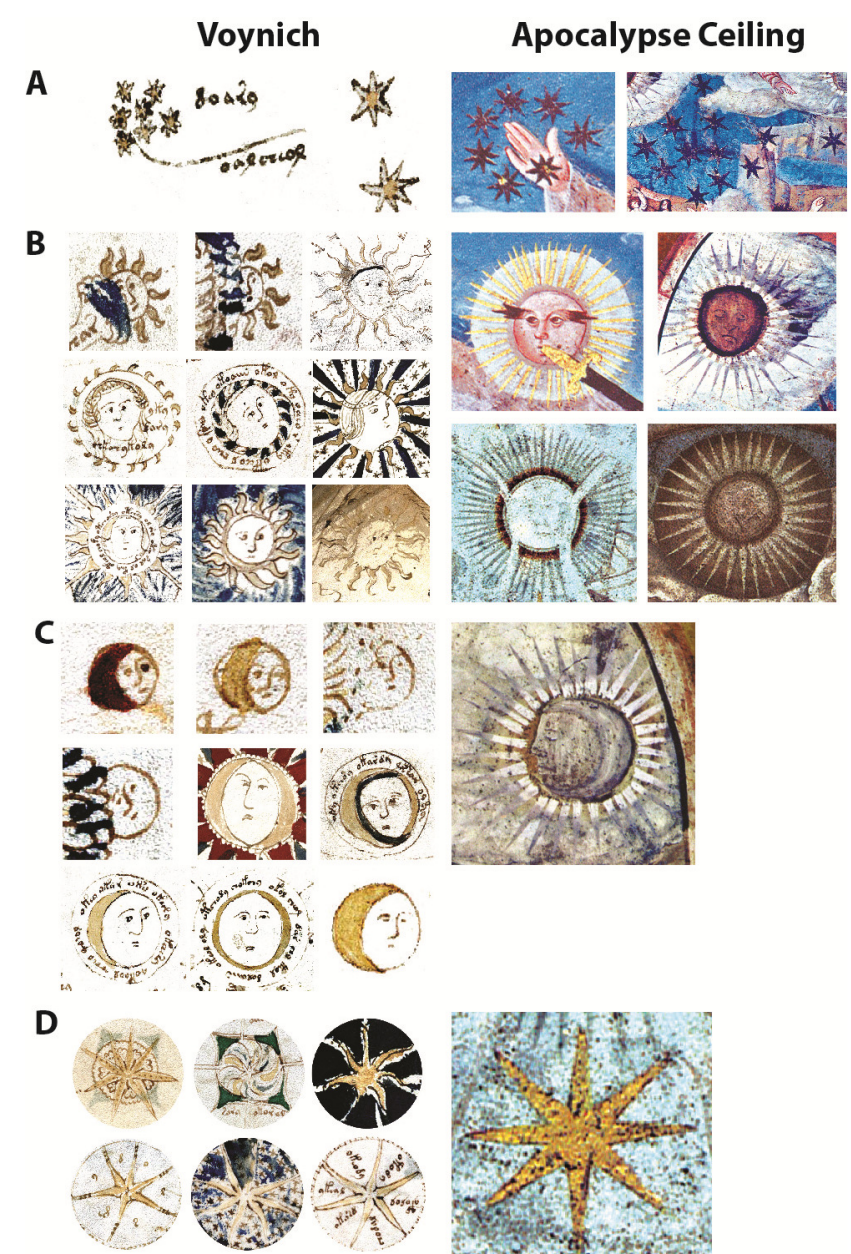

Fig. 7. Cosmology symbols in the Voynich Codex (left) and Gerson's Apocalypse (right): (A) stars; (B) suns; (C) moons; (D) planets
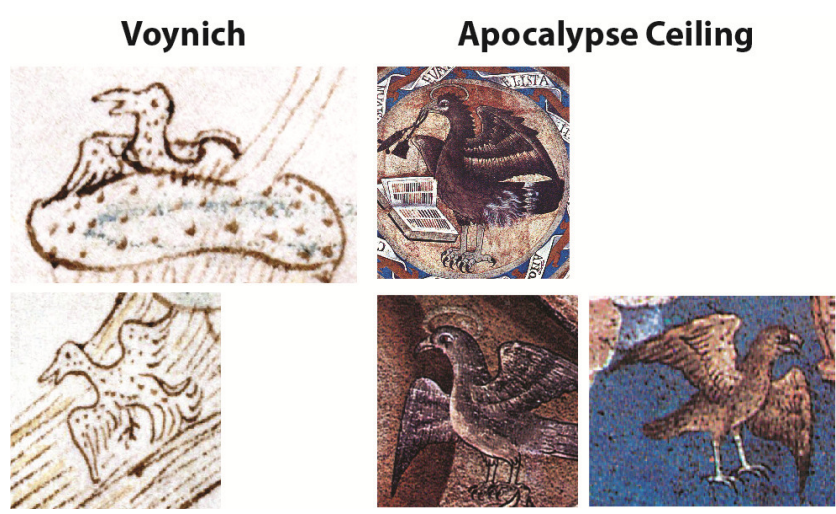

Fig 9. Birds in the Voynich Codex (left) and Gerson's Apocalypse (right)

The publication of The Casa del Deán: New World Images in a Sixteenth Century Mexican Mural Cycle by Penny C. Morrill (2014) has made available high definition images of this unique work by indigenous painters referred to as tlacuiloque. The murals painted about 1584 include two processions located in rooms known as the Salon of the Sibyls and the Salon of the Triumphs. Similarities between this mural and the Voynich Codes are as follows:

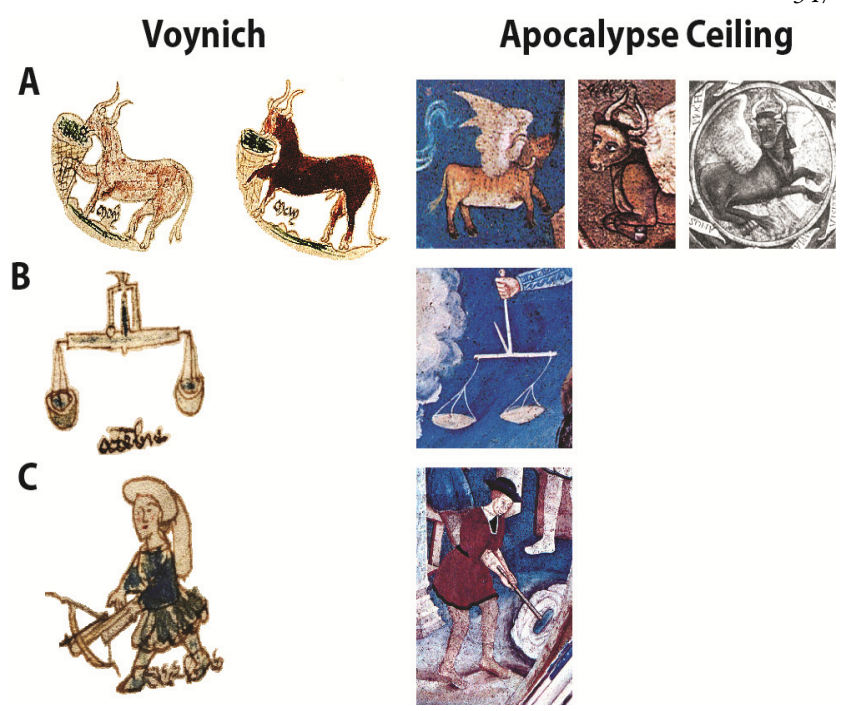

Fig. 8. Zodiac signs in the Voynich Codex (left) and Gerson's Apocalypse (right): (A) cattle; (B) sheep; (C) scales; (D) crossbow archer costume
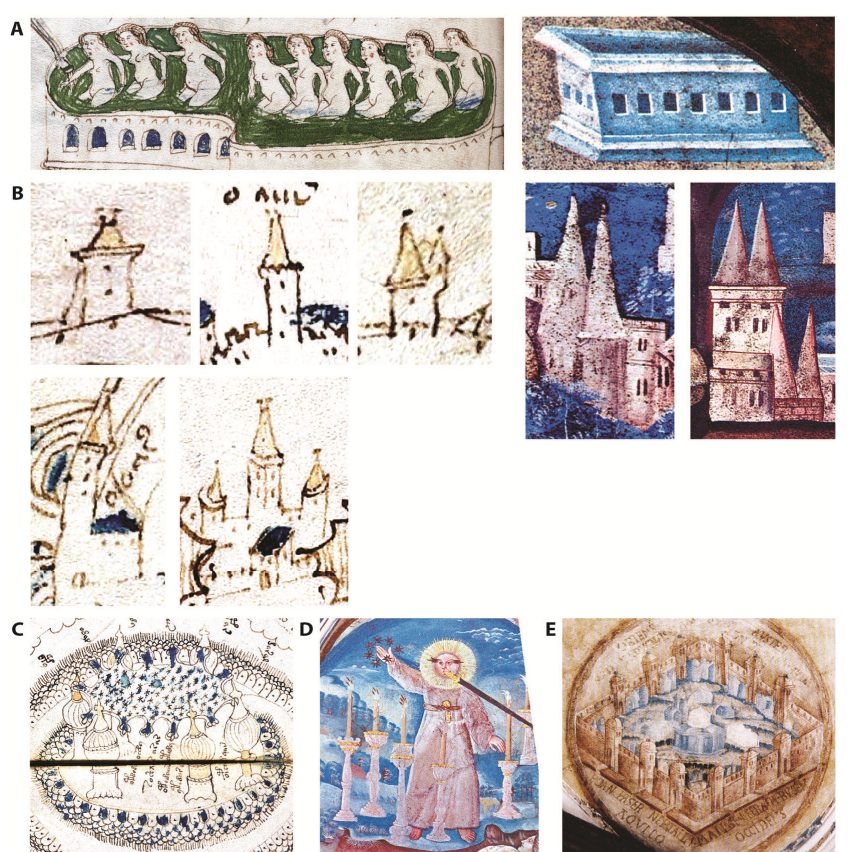

Fig. 10. Structures in the Voynich Codex (left) and Gerson's Apocalypse (right): (A) baths; (B) towers; (C) six qubba or ciboria in the Voynich Codex; (D) seven candlesticks in Gerson's Apocalypse painting; (E) map of Jerusalem in Apocalypse painting

\section{Women}

Faces of women (Fig. 11) are prominent in Voynich Codex and the Casa del Deán paintings, both in the sibyl processions on horseback and in friezes. Most of the women have hat coverings or hair ornaments. The faces are quickly drawn in Voynich Codex as compared to the more carefully drawings in the Casa del Deán paintings but it is conceivable that they are by the same hand. 
348

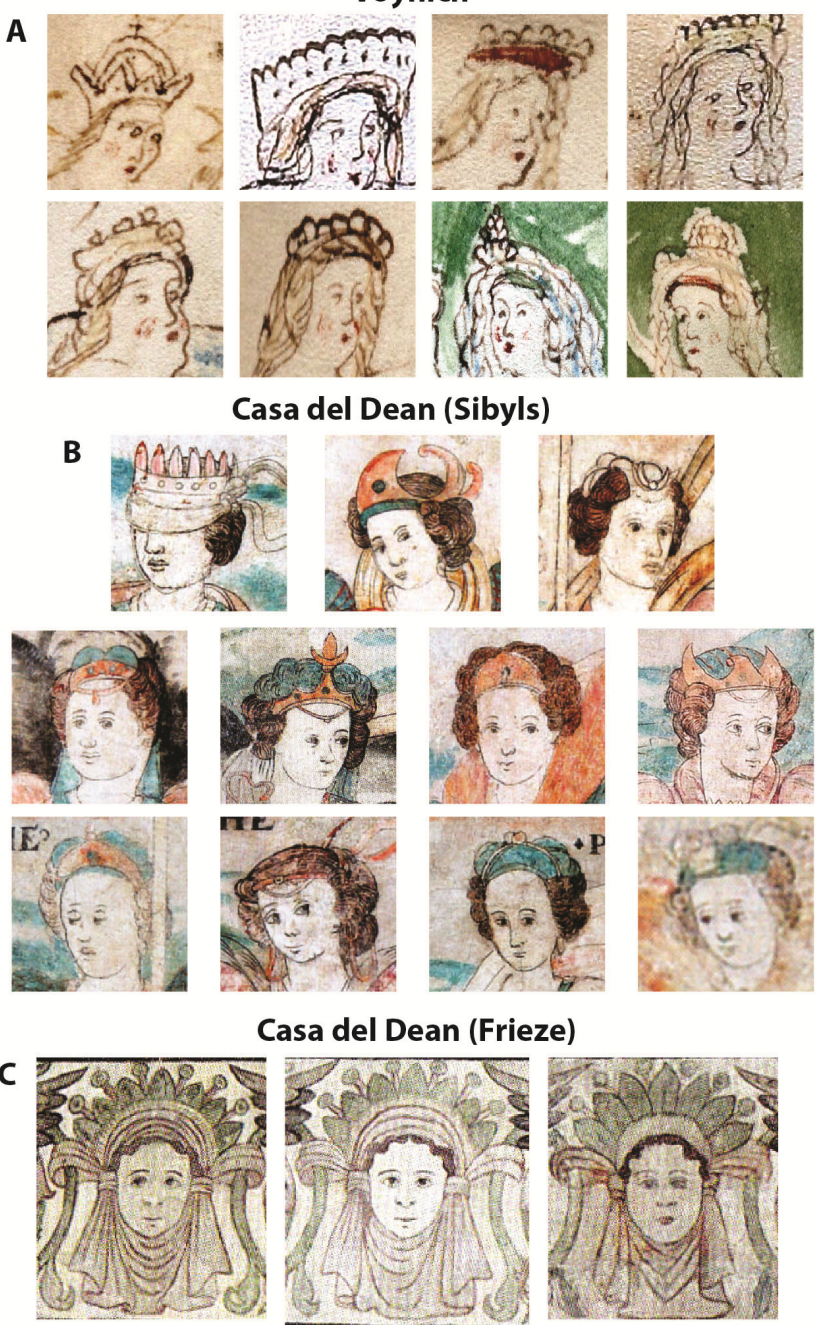

Fig. 11. Heads of nymphs: (A) the Voynich Codex; (B) sibyls; (C) frieze faces of Casa del Deán murals

\section{Nudity}

Both Voynich Codex (Fig. 12A) and the Casa del Deán (Fig. 12B) contain nude figures. There are hundreds of nude nymphs in the Balneological Section and zodiac circles of the Voynich Codex. In the Casa del Deán murals, nudity is present in the friezes; most are putti but some are centaur- or satyr-like. In a pool in the background of the Sibyl procession between the sibyllae Cucaea and Tiburtina in the west wall there are three pairs of nude bathers, and two are clearly male and female (Fig. 12C).

Gaspar de Torres: Doctor of Medicine, Licenciate, Master of Students, Governor of Cuba

With the identification of Gerson's initials in folio $1 \mathrm{v}$ of the Voynich Codex, the phytomorph in folio 1v was carefully examined for the presence of other embedded initials or names (Fig. 2B). Alternating contrasts in the brown strokes of the bud of the tiff file of Ipomoea arborescens (folio 1v) by Arthur O. Tucker revealed the name "Gasp. Torres" (Fig. 2C) but a full multi-spectral analysis of the original codex is needed. We are convinced the name refers to Gaspar de Torres, known to be maestre de niños (master of students) at the Colegio de Santa Cruz in Tlatelolco (SilverMoon, 2007).
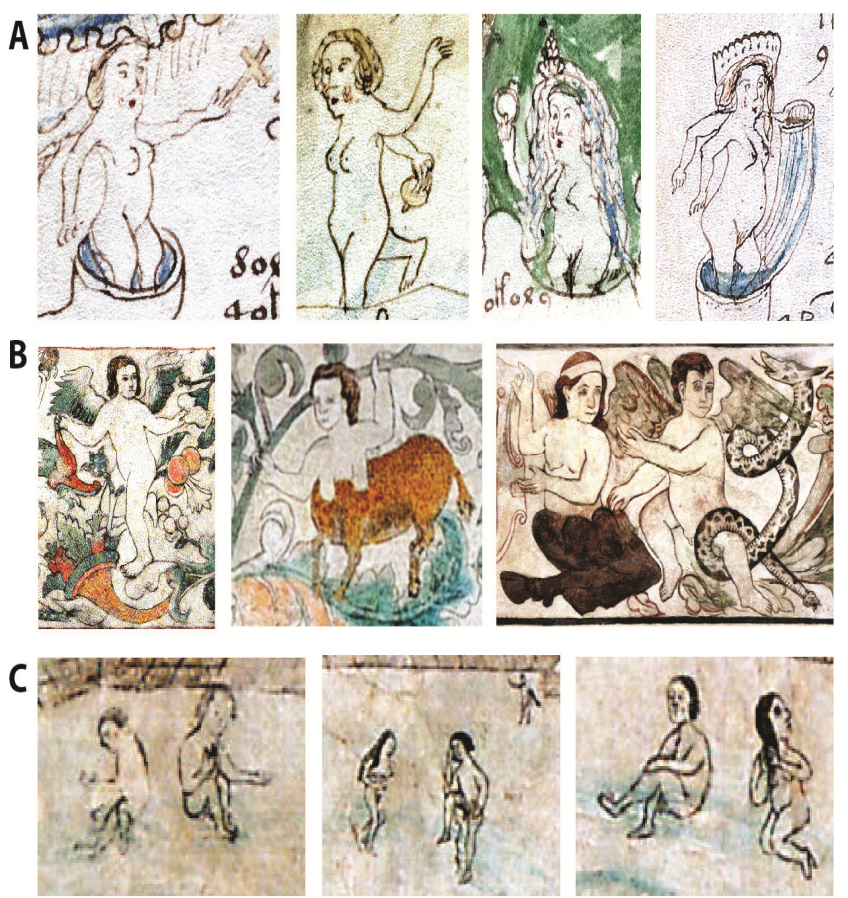

Fig. 12. Nude figures in the Voynich Codex (A) and Casa del Deán murals $(B, C)$

\section{Biography}

Gaspar de Torres was born in Santo Domingo in the early decades of the sixteenth century. His father, Melchior / Melchor de Torres, owned sugar plantations in Hispaniola including 900-1000 slaves. Melchior's half-brother, also named Gaspar de Torres, was probably born in Malaga, Spain, and became the leading slaver in Hispaniola from 1535-1540. The family included influential and wealthy relatives: Cousin Luis de Villanueva Zapata, abrogado (judge) and wealthy hacienda owner in Mexico, and cousin Diego de Villanueva Zapata, Fiscal Audiencia (crown attorney) of Panama (Helps, 1857; Chevalier, 1982; Cortés López, 1995; Kellenbenz and Walter, 2001; Schwartz, 2004).

Gaspar was well educated and attended the La Real Pontificia Universidad de México (Royal and Pontifical University of Mexico), the first university of Mexico established on September 21, 1551 for the education of the Spanish (Orozco y Berra, 1856; Carreño, 1961; Torre Villar, 1991; Pavón Romero, 1992; Salvador, 1998). Gaspar de Torres was awarded the doctorate degree in medicine on August 31, 1553. Later in a career change, Gaspar was awarded the degree of Licentiate (Lic.) in 1569. The licentiate degree was influential as explained by Herrera (2003): "On a much higher plane stood the small number of licentiates working the Audiencia [court established to hear royal justice]. They mainly adjudicated disputes over land and inheritance. The majority of those who held licentiates in law arrived as officials attached to the Audiencia... As a result of their university training and association with royal institutions, licentiates had a ready-made bigh-status niche that outstripped almost any other position that notaries and other sin similar professions could expect to attain". He was also employed at La Real Pontificia Universidad de México from December 14, 1569 to August 26, 1571, notably in company of his older friend, Damián Sedeño (Vazquez, 
2002). Gaspar de Torres then became a staff member as master of students of the Imperial College of Tlatelolco, based on records from 1568 to 1572 . This institution was originally created to educate the sons of the Aztec nobility for possible ordination as priests. The College had been formally established on January 6, 1536 but had, in fact, existed since August 8, 1533. On January 21, 1568, Torres was paid to teach students to read and write, and there are records of other payments in 1572 (Anonymus, 1892; Gómez Canedo, 1982; Kobayashi, 2007; SilverMoon, 2007). Most importantly, the Colegio had the only scriptorium in New Spain (Gravier, 2011), which would have had vital supplies of inks, pigments, paper, parchment, and vellum not ordinarily available elsewhere. Juan Gerson may have been associated with the Colegio during this time, although no period citation has yet been uncovered.

Gaspar de Torres also signed two documents as in interpreter and scribe for land rights of natives in Tulancingo, Hidalgo in 1569 (Carrasco, 1963). This would indicate he was fluent in Nahuatl, the language of the Aztecs, and familiar with other languages in the region.

There is evidence that Gaspar de Torres moved to Santo Domingo and records place him there on July 9, 1572, 1578, and 1579 (Autos entre partes Santo Domingo, 1575-1580; Caudevilla y Escudero et al., 1788; Cipriano de Utera, 2014; Poder Judicial de la República Dominicana, 2016). In 1579, Gaspar de Torres was appointed by the Audiencia to Cuba as governor pro tempore on half salary. He arrived on October 3, 1579 in Cuba and assumed office in January 1580. Yet, he fled eight months later before the arrival of his successor, D. Gabriel de Lujan, as a result of accusations by the Royal Treasurer, Juan Bautista de Rojas, that he looted the treasury (Blanchett, 1866; Wright, 1916; Johnson, 1920).

Gaspar de Torres was reported to be in Guatemala in 1584, and eventually settled in San Isidoro (now part of Panama City, Panama) $1595-1598$ as an estate lawyer. He was probably aided by his influential cousin of the Audiencia in Panama, Diego de Villanueva Zapata (Herrera, 2003; Viforcos Marinas, 2005).

\section{Association with the Voynich Codex}

This brief biography of Gaspar de Torres has many gaps but a number of facts can be gleaned that relate to the conjecture that he was associated with the Voynich Codex.

1. The key evidence is that his name ("Gasp. Torres") along with the ligated initials of Juan Gerson, Tlacuilo on folio 1v, appear on the first botanical image. This suggests collaboration between him and the painter Juan Gerson.

2. As master of students at the College of Santa Cruz, and scribe and interpreter for natives of Tulancingo, Hidalgo, we can assume that Gaspar de Torres was sympathetic to Aztec culture and familiar with the Aztec intellectual community at the College that included Antonio Valeriano, Martin Jacovita, Martin de la Cruz, Juan Badiano, Pedro de San Buenaventura, Juan Bautista de Pomar, as well as Fray Bernadina de Sahagún (Klor de Alva et al., 1988), at one time Dean of the College and pioneering ethnographer of the Aztecs.

3. His biography suggests de Torres was fluent in many languages including $16^{\mathrm{th}}$ century Latin American Spanish, Nahuatl, Latin, and Taino and perhaps other languages of Central Mexico. This extraordinary linguistic ability, along with his doctorate in medicine, could explain the Spanish-, and Nahuatl-derived names of the plants deciphered in the
Voynich Codex (Tucker and Talbert, 2013; Tucker and Janick, 2016). Taino was the language of the indigenous Indians in Hispaniola, and some of the deciphered plant names in the Voynich Codex are phonetic derivatives from that language, e.g., mäguoey or maguey (Agave sp. on folio 100r \#4) and macanol after the macana-like leaf (Philodendron sp. on folio 100r\#7).

4. Another clue to the approximate date of the Voynich Codex is indicated by the Codex Osuna. The Codex Osuna is a set of seven documents created to present evidence against the government of Viceroy Luis de Velasco during the inquiry of Jerónimo de Valderrama 1563-1566. It was an administrative document, not comparable to other codices from the era, and because it was created on order of Phillip II, it would have been sent to Seville shortly after completion. Not only are many symbols of the Voynich Codex similar to the handwriting in the Codex Osuna), but the Codex Osuna included claims of non-payment for various goods and services, including building construction and domestic help, i.e., the estate law of interest to Gaspar de Torres. Most significantly, Torres' close friend, Lic. Sedeño, gave testimony in the Codex Osuna in 1565 (Chavez Orozco, 1947).

5. His influential family, and rise to Governor of Cuba would indicate political skills and a wide circle of wealthy and influential acquaintances.

6. His abrupt leave from Mexico to Santo Domingo in 1572 suggests de Torres had something to hide. It is clear from that the text of the Voynich Codex was written after the illustrations were drawn so that it is likely the author, not the illustrator, would have been in possession of the manuscript. One reason for his departure to Santo Domingo may have been fear of the Inquisition. Although the Spanish Inquisition had been spottily applied in New Spain since 1536, the Spanish Inquisition was formally and vigorously introduced into New Spain in 1571. In 1571 and 1572, a new inquisitor, Dr. Moya de Contreras, began a widespread purge of prohibited books. In the Edict of Faith Issued by Inquisitor Dr. Pedro Moya de Contreras in Mexico City, October 10, 1576, it was stated: "Also, if you should know about any person who uses spells, incantations, charms, or conjures up spirits, or commits any other type of superstitious enchantments, or uses any other type of witchcraft, even if they are medicinal curers, or if anyone should have a copy of any type of book of spells or other superstition or any other type of probibited book, they should be denounced. And we order that anyone who should possess these books or have them read them should denounce themselves within the space of fifteen days before Us or Our other Inquisitors or their commissaries so that these writings can be examined and reviewed" (Chuchiak, 2012). The contents of the Voynich Codex would have been particularly offensive to the Inquisitor of the Spanish Inquisition, in view of the presence of the kabbalah imagery and the fact that the text was written in a symbolic cypher. Not only would it have been burned if found, but the owner would have been punished appropriately. Further examples are chronicled by Lossa (1642), Carmichael (1959), Greenleaf (1961), and Starr (1987). Santo Domingo offered sanctuary, beyond the pale of the Spanish Inquisition because its economy had severely declined since the Conquest of Mexico in 1521, later serving only as a way-station for slavers and dealers in contraband (Vizuete Picon, 1890).

The biography of Gaspar de Torres suggests possible paths 
350

of the Voynich Codex from the New World to Rudolph II, Emperor of the Holy Roman Empire. We conjecture that Gaspar de Torres, as the author of the manuscript now known as the Voynich Codex, was in possession of it when he left Tlatelolco to go to his home in Santo Domingo. He either left it in Santo Domingo when he became governor of Cuba in 1580 , or brought it back when he fled Cuba in the same year. If so, the manuscript could have been part of the booty captured by the expedition of Sir Francis Drake during his military campaign in the Caribbean, 1585-1586 (Kelsey, 1998; Sugden, 2006; Dean, 2010;). From January 1 to 31, 1586, the forces of Drake destroyed over a third of Santo Domingo, then pillaged Cartagena, raided Saint Augustine, and rescued the English colonists at Roanoke, returning to Plymouth, England on July 26, 1586. The soldiers who plundered Santo Domingo were under the command of Christopher Carleill on the ship Tiger. Carleill was the stepson of Sir Francis Walsingham, spymaster of Queen Elizabeth I. John Dee (1527-1608) occult philosopher, mathematician, and cabalist was a secret agent (the original agent 007) to Walsingham.

Dee has long been considering either as an author or conveyer of the Voynich Codex. The Codex if part of the booty of Drake's fleet would have belonged to the Government (Alford, 2012), but may somehow have reached Dee who was in Central Europe from 1583 to 1589, including Poland, Prague, and Třeboň. John Dee, had a private audience with Emperor Rudolph II in 1584, and Roberts and Watson (1990) state Dee was much in contact with the Emperor from 15841586. Dee was also in correspondence with Walsingham in 1586-1587, and Francis Garland acted as a courier between Dee and Walsingham (Parry, 2011). A 1665 letter by Joannes Marcus Marci to Athanasius Kircher contains hearsay evidence that the book [Voynich Codex] belonged to Emperor Rudolph who gave 600 ducats to the bearer and thought it was the work of Roger Bacon (Kennedy and Churchill 2006). In Dee's spiritual diary of October 17, 1586 there is evidence that he had 630 ducats on that day. At this time, Dee was desperate for funds to pay off Francesco Pucci, who would have dragged him off to a Rome under orders of the Pope. The rumor of Rudolph paying 600 ducats for the Voynich manuscript, and Dee having 630 ducats in 1586 seems more than a coincidence suggesting that Dee was "the bearer of the book" but there are many skeptics including Rene Zandbergen (2016). John Dee's occultist friend, Edward Kelley, was also retained as Alchemist by Rudolph II after 1589 . Finally, the book could have been purchased in London by agents of Rudolf II dispersed throughout Europe to collect for his Kunstkammer (Fučiková et al., 1997).

\section{Conclusions}

Based on plant, animal, and mineral identifications we are convinced the Voynich Codex is a $16^{\text {th }}$ century New World document and thus dismiss all European claimants as authors. The 1425 dating of the vellum by mass spectrometry (Stolte, 2011) does not date the text as vellums were reused (a palimpsest). We see in the Voynich Codex the fusion of the submerged, dying, indigenous culture of the Aztecs and the medieval culture of Spain influenced by conquistadors, the Catholic Church, Jews, and Arabs.

Iconographic analyses of the ligated "JGT" initials in folio $1 \mathrm{v}$ of the Voynich Codex, the Apocalypse Paintings in
Tecamachalco (1562), and the Casa del Dean murals in Pueblo (1584), suggest that Juan Gerson, Tlacuilo, is associated with all three works. The artistic similarities between the paintings at Tecamachalco of 1562, some of the murals of Casa del Deán of 1584, and the Voynich Codex underscore the extraordinary accomplishments of the artist Juan Gerson, an indio ladino, a native Amerind of two worlds - the remnants of the Aztec empire and the emerging colonial power of New Spain.

The presence of the name "Gasp. Torres" on folio $1 \mathrm{v}$ indicates that Gaspar de Torres was also associated with this manuscript, probably as the author or coauthor or of the text. Gaspar de Torres - well educated, multilingual, and advocate of Indian land rights was master of students between 1568 and 1572 of the College of Santa Cruz, in Tlatelolco, Mexico, established in 1536 for the education of sons of Aztec nobility. We conjecture that Juan Gerson as an indigenous, wellconnected, talented Indian may have been associated with the Colegio in some manner and could have used its scriptorium as a source of vellum and pigments. This would explain his collaboration with Gaspar de Torres. The flight of Gaspar de Torres to Santo Domingo in 1572 suggests fear of severe punishment by the Inquisition for possession and authorship of would have been considered a heretical manuscript.

Based on the presence of the ligated initials of Juan Gerson and the name of Gasp. Torres on the first herbal folio, as well as the iconographic and the biographical evidence, we propose Juan Gerson and Gaspar de Torres as plausible claimants for illustrator and author of the Voynich Codex. Our assumption is that Voynich was composed in Tlatelolco between 1565 and 1572, probably during Torres tenure at College of Santa Cruz, a few years after the Apocalypse murals by Juan Gerson were completed, and soon after Codex Osuna was created from which some of the symbols of the text are derived.

\section{Acknowledgements}

We thank Anna L. Whipkey for her valuable assistance with the figures.

\section{References}

Alford S (2012). The watchers: A secret history of the reign of Elizabeth I. Bloomsbury Press, New York.

Anonymous (1892). Codice Mendieta: Documentos Franciscanos, Siglos XVIy XVII. Imprenta de Francisco Diazde Leon, México 2 Vols.

Autos entre partes Santo Domingo (1575-1580). Código de Referencia:

ES.41091.AGI/24.52.14//Justicia, 984 Título/Nombre Atribuído: Autos Entre Partes. Santo Domingo [f] 01-01-1575/31-12-1580 Nivel de Descripción: Fracción de Serie-Unidad de Instalación. Retrieved 2016 July 2 from http://censoarchivos.mcu.es/CensoGuia/fondo Detail.htm?id=930360.

Azpeitia RC (1972). Juan Gerson, Pintor indigena del sigo XVI - simbolo del mestizage - Tecamachalco Puebla. Fondo Editorial de la Plastica Mexicana, Mexico.

Blanchet E(1866). Compedia de la historia de Cuba. La Aurora del Yumuri, de Jose Curbeloy Herm., Matanzas.

Camelo Arredondo R, Gurría Lacroix J, Reyes Valerio C (1964). Juan Gerson, tlacuilo de Tecamachalco. Departamento de Monomuntos Coloniales, Instituto Nacional de Anthropolgia e Historia, México. 
CarmichaelJH(1959). Balsalobre on idolatry in Oaxaca. Boletín de Estudios Oaxaqueños 13:1-9.

Carrasco P (1963). Los caciques chichimecas de Tulancingo. Estudios de Cultura Náhuatl 4:85-91.

Carreño AM(1961). La Real y Pontificia Universide de Mexico 1536-1865. Universidad Nacional Autónoma de México, México.

Caudevilla y Escudero J, Mendel B, Consejo de Indias (Spain) (1788). Memorial ajustado, hecho de orden del real y supremo Consejo de Indias, con citatcion y asistencia de las partes, en el pleyto, que en grado de revista se sigue en el por el Senor Don Mariano Colón de Larreategui num. 64, del Consejo de Castilla, Superintendente General de Policía, Madrid.

Chávez Orozco L (1947). Codice Osuna. Ediciones del Instituto Indigenista Interamericano, Mexico D.F.

Chevalier F (1982). Land and society in Colonial Mexico: The great haciendas. Transl. A. Eustis. University ofCalifornia Press, Berkeley.

Chuchiak JF (2012). The inquisition in New Spain, 1536-1820: A documentary history.Johns Hopkins Press, Baltimore, Maryland.

Cipriano de Utera, Fray (2014). Historia militar de Santo Domingo (Documentos y noticias). Tomo II DN, República Dominicana, Santo Domingo.

Comegys JD (2014). The Voynich manuscript: Aztec herbal from New Spain. [pdffile created March 22, 2014, (02013] Retrieved 2014 August 23 from http://voynichms.com/wp-content/uploads/ 2014/03/ VMSAztecHerbal-JDComegys.pdf.

Cortés López JL (1995). 15441550: el período más prolífico en la exportación de esclavos durante el s. XVI. Análisis de un interesante document extrído del Archivo de Simancas. Espacio, Tiempo y Forma SerIV 8:63-86.

Dean, JS (2010). Tropics bound: Elizabeth's seadogs on the Spanish Main. History Press, Stroud, Gloucestershire, UK.

Du Bron M (2010). Le cheval Mexicain en Nouvelle-Espagne entre 1519 et 1639. PhD Thesis, École des Hautes Études en Sciences Sociales, Paris.

Fučiková E, Bradburne JM, Bukovinská B, Hausenblasová J, Konečný JL, Muchka I, Šronék M (Eds) (1997). RudolfII and Prague: The imperial court and residential city as the cultural and spiritual heart of Central Europe. Prague Castle Administration, Prague.

Gómez Canedo LG (1982). La educación de los marginados durante la Época Colonial: Escuelas y colegios para Indios y Mestizos en la Nueva España. Editorial Porrúa, México.

Gravier MG (2011). Sahagún's Codex and book design in the indigenous context. In: WolfG, Connors J (Eds). Colors between two worlds. The Florentine Codex of Barnardino de Sahagún. Officina Libraria, Milano pp 156-197.

Greenleaf RE (1961). Zumárraga and the Mexican Inquisition 1536-1543. Academy of American Franciscan History, Washington, DC.

Gutiérrez Haces J (2002). ¿La pintura novohispanica como una koine pictórica Americana? Anales del Instituto de Investigacioines Estéticas 24(80):47-99.

Helps A (1857). The Spanish conquest in America, and its relation to the history of slavery and to the government of colonies. Harper \& Brothers, New York.
Herrera R (2003) Natives, Europeans, and Africans in sixteenth-century Santiago de Guatemala. University of Texas Press, Austin.

Johnson WF (1920). The history of Cuba. Vol 1. Buck BF \& Co., New York.

Kellenbenz H, Walter R (2001). Oberdeutsche Kaufleute in Sevilla und Cadiz (1525-1560): Eine Edition von Notariatsakten aus den dortigen Archiven. Deutsche Handelsakten des Mittelalters und der Neuzeit. FranzSteinerVerlagVol 21.

KelseyH (1998). Sir Francis Drake, the Queen's pirate. Yale University Press, New Haven, CT.

Kennedy G, Churchill R (2006). The Voynich manuscript. Inner Traditions, Rochester, Vermont.

Klor de Alva JJ, Nicholson HB, Keber EQ (Eds) (1988). The work of Bernardino de Sahagún: Pioneer ethnographer of sixteenth-century Aztec Mexico. Institute for Mesoamerican Studies, University at Albany,NY.

Kobayashi JM (2007). La educación como conquista (empresa franciscana en México).ElColegiode México, México.

Kügelgen Hvon (Ed) (2013). Profecia y triunfo: la Casa del Deán Tomás de la Plaza: facetas plurivalentes. Iberoamericana, Madrid.

Landa Abrego ME (1992). Juan Gerson, tlacuilo. Gobierno del Estado de Puebla, Comisión Puebla V Centenario, Mexico.

Lossa F (1642). Vida que el siervo de Dios Gregorio Lopez hizo en algunos lugares dela Nueva España. Imprenta Real, Madrid.

Morrill PC (2014). The casa del deán: New World imagery in a sixteenth century Mexican mural cycle. University of Texas Press, Austin.

Motolinía, T de Benevente (1951). Motolinía's history of the Indians of New Spain. Transl. FB Steck. Academy of American Franciscan History, Washington, DC.

Niedermeier M (2002). Finalidad y función de modelos gráficos europeos. El ejemplo del ciclo de Juan Gerson en el convento de Tecamachalco, Puebla. In: Kügelgen $\mathrm{H}$ von (Ed). Herencias indigenas, tradiciones europeas y la mirada europea. Indigenes Erbe, europäische Traditionen und der europäische Blick. Actas del Coloquio de la Asociación Carl Justi y del Instituto Cervantes de Bremen, Bremen, del 6 al 9 de abril de 2000. Akten des Kolloquiums der Carl Justi-Vereinigung und des Instituto Cervantes Bremen, Bremen, 6-9 April 2000. Iberoamericana, Vervuert pp 95-121.

O'Neill H (1944). Botanical observations on the Voynich MS. Speculum 19(1):126.

Orozco y Berra M (1856). Apéndice al diccionario universal de historia y de geografia. AndradeJMyEscalanteF, México Vol 3.

Parry G (2011). The arch-conjuror of England, John Dee. Yale University Press, New Haven.

Pavón Romero A (1992). Universitarios y oidores: Un tipo de catedrático de leyes y cánones en el siglo XVI. Anuario Mexicano de Historia del Derecho4:161-171.

Poder Judicial de la República Dominicana (2016). Historia del Poder Judicial. Retrieved 2016 October 10 from http://www.poderjudicial. gob.do/poder_judicial/info_gral/historia_poder_judicial.aspx.

Roberts RJ, Watson A (Eds) (1990). John Dee's library catalogue. Biographical Society, London. 
352

Salvador RA (1998). Por el camino de las letras : el ascenso profesional de los catedráticos juristas de la Nueva Espana: sigo XVIII. Universidad Nacional Autónoma de México, México.

Sanchis Amat VM (2012). Francisco Cervantes de Salazar (1518-1575) y la patria del conocimiento: la soledad del humanista en la ciudad de Mexico. PhD Thesis, Alicante, Spain.

Schwartz SB (Ed) (2004). Tropical Babylons: Sugar and the making of the Atlantic world, 1450-1680. University of North Carolina Press, Chapel Hill.

SilverMoon (2007). The imperial college of Tlatelolco and the emergence of a new Nahua intellectual elite in New Spain (1500-1760). PhD Thesis Duke University Durham, North Carolina.

StarrJ (1987).Zapotec religious practices in the Valley of Oaxaca: An analysis of the 1580 "Relaciones Geograficas" of Philip II. Canadian Journal of NativeStudies 7:367-384.

Stolte D (2011). UA experts determine age of book 'nobody can read'. Retrieved 2012 July 25 from http://uanews.org/node/37825.

Sugden J (2006). Sir Francis Drake. Pimlico, London.

Torre Villar E de la (1991). La teología en Nueva España apuntamientos. Memorias dela Academia Mexicana dela Historia 34:5-61.
Townsend C (2016). Annals of North America: How the Nahuas of Colonial Mexico kept their history alive. Oxford University Press, New York.

Tucker AO, Talbert RH (2013). A preliminary analysis of the botany, zoology, and mineralogy of the Voynich Manuscript. Herbalgram 100:70-85.

Vázquez, RS (2002). Síntesis sobrela real y pontificia Universidad de México. Anuario Mexicano de Historia del Derecho 15:265-342.

Viforcos Marinas I (2005). La volatilidad de los legados Indinos. El caso de Ruy Díaz Ramírez de Quiñones y sus disposiciones testamentarias. Estudios Humanísticos Historia 2005(4):263-293.

VizuetePicon P (1890). Diccionaro enciclopedico Hispanico-Americano de literature, ciencias yartes. Montanery Simón, Barcelona Vol 5(2).

Wright IA (1916). The early history of Cuba, 1492-1586. Macmillan Co., New York.

Zandbergen R (2016). Earliest owners. In: Chandler R (Ed). The Voynich manuscript. Yale University Press, New Haven, Connecticut pp 1-9.

Zyats P, Muysak E, Stenger JM, Lemay F, Bezur A, Driscoll DD (2016). Physical findings. In: Clemens R (Ed). The Voynich manuscript. Yale University Press, New Haven, Connecticut pp 23-37. 